Published in final edited form as:

Am J Physiol Gastrointest Liver Physiol. 2007 June ; 292(6): G1770-G1783. doi:10.1152/ajpgi.

00249.2006.

\title{
Enteroendocrine cells express functional Toll-like receptors
}

\author{
Milena Bogunovic ${ }^{1,{ }^{*}}$, Shaival H. Davé ${ }^{1,{ }^{*}}$, Jeremy S. Tilstra ${ }^{2,3}$, Diane T. W. Chang ${ }^{4}$, Noam \\ Harpaz $^{5}$, Huabao Xiong ${ }^{1}$, Lloyd F. Mayer ${ }^{2,3}$, and Scott E. Plevy ${ }^{6}$ \\ ${ }_{1}^{1}$ Immunobiology Center, The Mount Sinai School of Medicine, New York, New York \\ ${ }^{2}$ Department of Medicine, University of Pittsburgh School of Medicine, Pittsburgh, Pennsylvania \\ ${ }^{3}$ Department of Immunology, University of Pittsburgh School of Medicine, Pittsburgh, \\ Pennsylvania \\ ${ }^{4}$ Department of Pharmacology, University of Pittsburgh School of Medicine, Pittsburgh, \\ Pennsylvania \\ ${ }^{5}$ Department of Pathology, The Mount Sinai School of Medicine, New York, New York \\ ${ }^{6}$ Division of Gastroenterology and Hepatology, University of North Carolina School of Medicine, \\ Chapel Hill, North Carolina
}

\section{Abstract}

Intestinal epithelial cells (IECs) provide a physical and immunological barrier against enteric microbial flora. Toll-like receptors (TLRs), through interactions with conserved microbial patterns, activate inflammatory gene expression in cells of the innate immune system. Previous studies of the expression and function of TLRs in IECs have reported varying results. Therefore, TLR expression was characterized in human and murine intestinal sections, and TLR function was tested in an IEC line. TLR1, TLR2, and TLR4 are coexpressed on a subpopulation of human and murine IECs that reside predominantly in the intestinal crypt and belong to the enteroendocrine lineage. An enteroendocrine cell (EEC) line demonstrated a similar expression pattern of TLRs as primary cells. The murine EEC line STC-1 was activated with specific TLR ligands: LPS or synthetic bacterial lipoprotein. In STC-1 cells stimulated with bacterial ligands, NF- $\kappa \mathrm{B}$ and MAPK activation was demonstrated. Furthermore, the expression of TNF and macrophage inhibitory protein- 2 were induced. Additionally, bacterial ligands induced the expression of the anti-inflammatory gene transforming growth factor- $\beta$. LPS triggered a calcium flux in STC-1 cells, resulting in a rapid increase in CCK secretion. Finally, conditioned media from STC-1 cells inhibited the production of nitric oxide and IL- 12 p 40 by activated macrophages. In conclusion, human and murine IECs that express TLRs belong to the enteroendocrine lineage. Using a murine EEC model, a broad range of functional effects of TLR activation was demonstrated. This study suggests a potential role for EECs in innate immune responses.

\section{Keywords}

innate immunity; cytokines; intestinal epithelial cells; mucosal immunity

\section{Copyright $@ 2007$ the American Physiological Society}

Address for reprint requests and other correspondence: S. E. Plevy, Div. of Gastroenterology and Hepatology, Univ. of North Carolina School of Medicine, 103 Mason Farm Rd., Campus Box 7032, 7341C MBRB, Chapel Hill, NC 27599-7032 (scott_plevy@med.unc.edu)..

M. Bogunovic and S. H. Davé contributed equally to this work. 
ноST DEFENSE against microorganisms relies on both innate and adaptive immune responses. The molecular components of innate immunity are evolutionarily conserved over an extraordinary spectrum of life forms, from plants to mammals (28). Receptors of the innate immune system are known as pattern recognition receptors (PRRs). PRRs identify and bind to a conserved set of molecular structures expressed on diverse organisms. Hence, the innate immune system has evolved receptors that can recognize essential and unique features of microbial structure, such as LPS, bacterial lipoproteins (BLPs), mannans, and doublestranded RNA $(18,27)$. One evolution-arily conserved family of PRRs, the Toll-like receptors (TLRs), is a particularly important component of the innate immune response. TLRs are transmembrane molecules composed of multiple extracellular leucine-rich repeats, a single transmembrane domain, and an intracellular signaling domain. TLRs activate the transcription factor NF- $\kappa \mathrm{B}$ and inflammatory gene expression through an evolutionarily conserved signal transduction pathway (28).

Intestinal epithelial cells (IECs) serve as a physical and immunological interface with microbial flora that colonize and traverse the intestinal lumen. Among the immunological functions ascribed to IECs are cytokine production upon intracellular infection with pathogenic intestinal bacteria $(9,20,21)$. This implicates IECs as important participants in innate immune responses of the intestinal mucosa. Therefore, it is of great interest and potential clinical relevance to determine the role of TLRs in IEC innate immune responses. In human tissue sections, TLR2 and TLR4 were "barely detectable" on IECs from human tissue sections (5). Upregulation of TLR4 in the inflammatory bowel diseases (IBDs) of Crohn's disease (CD) and ulcerative colitis (UC) and downregulation of TLR3 in CD but not UC was also described (5). Conversely, another group (14) reported that TLR2 and TLR4 were not expressed in IECs from the normal or inflamed human intestine and that, in fact, TLR expression was confined to lamina propria macrophages from inflamed tissue sections. Likewise, there are controversial reports about TLR4 function in human IEC lines, with some reporting LPS responsiveness $(6,35)$ and others suggesting LPS resistance due to the absence of TLR4 and/or a coreceptor $(2,32,49)$ or induction of inhibitory signaling molecules (35). Furthermore, a functional role for TLR5 has been suggested, and one report has described hyporesponsiveness of TLR2 in IEC lines $(6,13,30)$. Therefore, the nature of intestinal epithelial TLR expression and function remains incompletely understood.

In this study, abundant expression of multiple TLRs was demonstrated in human and murine IECs that reside primarily in the crypt and belong to the enteroendocrine lineage. Possible functional consequences of TLR expression and activation were explored using an enteroendocrine cell (EEC) line. This study suggests a potential role for EECs in innate immune responses and shows that EEC-bacterial interactions help maintain mucosal immune homeostasis.

\section{MATERIALS AND METHODS}

\section{Cell lines and reagents}

The murine EEC line STC-1 (Mark Babayatsky, The Mount Sinai Medical School, New York, NY) was maintained in DMEM with $4.5 \mathrm{~g} / 1$ glucose and $\mathrm{L}_{\text {-glutamine supplemented }}$ with $10 \%$ FBS (Gemini) and 1\% penicillin-streptomycin (Cellgro) and kept in a humidified incubator at $37^{\circ} \mathrm{C}$ and $5 \% \mathrm{CO}_{2}$. Human embryonic kidney (HEK)-293T cells and human intestinal epithelial Caco-2 cells were grown in subconfluent monolayers in DMEM with 4.5 $\mathrm{g} /$ glucose and $\mathrm{L}$-glutamine supplemented with $10 \%$ FBS. Recombinant transforming growth factor (TGF)- $\beta_{1}$ was purchased from R\&D Systems. The synthetic BLP (sBLP) $\mathrm{Pam}_{3}$ Cys-SKKKK was purchased from EMC Microcollections (Tuebingen, Germany). LPS from Salmonella enteritidis was purchased from Sigma and was repurified to eliminate TLR2-contaminating ligands by modified phenol extraction as previously described (16). 


\section{Expression plasmids}

Multimerized NF-kB DNA binding element luciferase reporter was obtained from Dr. Adrian Ting (The Mount Sinai School of Medicine, New York, NY). A heat shock protein (HSP) promoter- $\beta$-galactosidase reporter plasmid was used to normalize for transfection efficiency as previously reported (56). A constitutively active CD4-TLR4 fusion protein plasmid was obtained from Ruslan Medzhitov (Yale University) (29).

\section{Murine macrophages}

Bone marrow (BM) from femurs of C57BL/6 mice were flushed with washing medium (RPMI-1640 with $1 \%$ penicillin-streptomycin), passed through a $70-\mu$ m nylon cell strainer into a 50-ml conical tube, and spun down at 1,500 rpm for $5 \mathrm{~min}$. Red blood cells were lysed using sterile-filtered $0.8 \%$ ammonium chloride, washed twice with washing medium, and resuspended in complete medium (washing medium with 10\% FBS). BM cells were seeded in complete medium in a $150-\mathrm{mm}$ dish and differentiated using recombinant murine granulocyte-macrophage colony-stimulating factor (GM-CSF; $20 \mathrm{ng} / \mathrm{ml}$, R\&D Systems). At day 3, another $25 \mathrm{ml}$ of fresh culture medium containing GM-CSF were added to the culture plates. At day 7, the cells, representing the BM-derived macrophage population, were harvested. For peritoneal macrophages, $3 \mathrm{ml}$ of $3 \%$ thioglycollate were injected intraperitoneally into C57BL/6 mice. Five days later, mice were euthanized, and adherent cells isolated from peritoneal exudate fluid were used in experiments.

\section{Transient gene expression assays and cell activation}

STC-1 cells were plated in six-well plates. Once cells were 50-80\% confluent, they were transiently transfected using Superfect (Qiagen) reagent following the manufacturer's protocol. Cells were transfected with the reporter genes NF- $\mathrm{kB}$-luciferase $(0.6 \mu \mathrm{g})$ and HSP$\beta$-galactosidase $(0.5 \mu \mathrm{g})$ in $1.1 \mathrm{ml}$. Following transfection, cells were activated with bacterial ligands. Eight hours after activation, cells were lysed in reporter lysis buffer, and luciferase activity was measured with a luciferase assay system (Promega) using Turner Designs Luminometer TD20/20. Transfection efficiency was assessed by $\beta$-galactosidase activity in the same cell lysates. The ratio of the two parameters (luciferase: $\beta$-galactosidase) was used for data presentation as previously reported (56).

\section{MAPK activation}

Cells were stimulated for the times shown in Fig. 7. Cells were harvested and lysed as described previously (54). Whole cell lysates were immunoblotted for phosphorylated ERK1/2 MAPK and total ERK2 MAPK using specific polyclonal antibodies (Santa Cruz Biotechnology).

\section{Immunohistochemistry}

Paraffin-embedded tissue sections of the histologically normal human colon and ileum derived from surgical resections of patients with colon cancer were deparaffinized and microwaved in antigen unmasking solution (Vector Laboratories) for $15 \mathrm{~min}$. If cryosections were used, slides were fixed in $10 \%$ formalin. Intestinal sections were procured from the Department of Pathology, The Mount Sinai Medical Center, and had been deidentified of any patient data as part of an Institutional Review Board-approved tissue bank. C57B1/6 murine colonic sections were fixed in $2 \%$ paraformal dehyde and incubated overnight in $30 \%$ sucrose before being cryosectioned.

For diaminobenzidine (DAB) staining, slides were placed in $0.3 \% \mathrm{H}_{2} \mathrm{O}_{2}$-methanol for 10 min to block endogenous peroxidase activity. Slides were preincubated with PBS containing $5 \%$ serum of the same allotype as the secondary antibody. Isotype-matched purified 
immunoglobulin or primary antibody was applied. Slides were washed in PBS and incubated with a secondary antibody against the Fc fragment of the primary antibody. Depending on the immunohistochemistry technique, secondary antibodies were labeled with a fluorescent marker (Alexa488, Cy3, FITC, or Texas red), biotin, or alkaline phosphatase. After slide had been incubated with biotin-labeled antibodies, horseradish peroxidase-streptavidin was applied to the slides followed by DAB solution (ImmunoCruz Staining System, Santa Cruz Biotechnology). If alkaline phosphatase-labeled antibody was used, slides were incubated with levamisole solution (Vector Laboratories) to block human alkaline phosphatase, and slides were stained using the Red Alkaline Phosphatase Substrate Kit I (Vector Laboratories).

Antibody binding to antigen was neutralized by preabsorption with specific blocking peptides. Anti-TLR1 and anti-TLR2 antibodies were preincubated with a fivefold excess of corresponding blocking peptides (Santa Cruz Biotechnology) overnight at $4^{\circ} \mathrm{C}$. Afterward, the antibody-peptide solution was applied to the slides.

Nuclei were counterstained with Harris Modified Hematoxylin (Fisher) or with Hoescht stain. Slides were dehydrated and mounted using Vectashield mounting medium with 4',6diamidino-2-phenylindole (Vector Laboratories), gelvatol for fluorescent dyes, or Immumount (Shandon, Pittsburgh, PA) for DAB and Texas red dyes.

Slides were visualized with a microscope configured for fluorescence imaging (Olympus BX60 or Olympus Provis), fitted with a cooled charge-coupled device (CCD) color camera and frame grabber (Optronix or Magnifier) or confocal laser scanning microscope (Leica TCP-SP), and analyzed using Metamorph (Molecular Devices, Sunnyvale, CA).

\section{Antibodies and their working concentrations}

Anti-human TLR1, TLR1-biotinylated, TLR2, TLR4, and TLR6 antibodies (goat polyclonal, Santa Cruz Biotechnology) were used at concentrations between 2 and $5 \mu \mathrm{g} / \mathrm{ml}$; anti-human TLR4 and anti-TLR4/MD2 antibodies (rabbit polyclonal, eBioscience) were used at a concentration of $5 \mu \mathrm{g} / \mathrm{ml}$. All anti-human TLR antibodies used (except TLR1) were cross reactive against mouse TLRs. Anti-serotonin antibody (NCLSEROTp, rabbit polyclonal, Novocastra, UK; or rabbit polyclonal, Calbiochem) was diluted 1:200 or 1:500, respectively. Anti-multicytokeratin-4/5/6/8/10/13/18 antibody (NCL-C11, mouse monoclonal, Novocastra) antibody was diluted 1:10. Biotinylated secondary antibodies were obtained from Santa Cruz Biotechnology.

\section{RT-PCR, nitrite determination, and ELISA}

Cells were harvested by TRIzol (Invitrogen), and total RNA was isolated as per the manufacturer's protocol. For TLR mRNA detection, RNA samples were treated by DNaseI (Ambion). For reverse transcription, a SuperScript Preamplification System (Invitrogen) was used. PCR amplification was performed with Taq polymerase (Promega). Primer design and specific conditions are shown in Table 1. All sequences were designed based on cDNA sequences obtained from the GenBank database. For ELISA, STC-1 supernatants were removed and assayed for the presence of TNF (BD Pharmingen), macrophage inhibitory protein (MIP)-2, and TGF- $\beta$ (R\&D Systems) following the manufacturer's protocol. The stable nitric oxide (NO) metabolite nitrite was measured using Griess reagent as previously described (53). Values were measured using a plate reader and SOFTMax Pro version 4.0 software (Molecular Devices). 


\section{CCK enzyme immunoassay}

STC-1 cells were pretreated for $30 \mathrm{~min}$ in the presence or absence of $20 \mu \mathrm{M}$ BAPTA-AM (Calbiochem) and then stimulated for 10,30, 60, or 180 min with media, LPS, sBLP, or bombesin (BBS) (AnaSpec, San Jose, CA). Supernatants were centrifuged to remove cellular debris and analyzed for CCK by enzyme immunoassay (EIA) following the manufacturer's protocol (Phoenix Pharmaceutical, Belmont, CA).

\section{Calcium imaging}

STC-1 cells in six-well plates were loaded in $\mathrm{Ca}^{2+} / \mathrm{Mg}^{2+}$-free PBS (Invitrogen) containing $10 \%$ FBS and $5 \mu \mathrm{M}$ fura2-AM (Molecular Probes) diluted from a $1 \mathrm{mM}$ DMSO stock for $15-20 \mathrm{~min}$ at $37^{\circ} \mathrm{C}$. After being loaded, cells were thoroughly rinsed with $10 \%$ FBS-PBS. For fluorescence recording, we used a BX61WI Olympus Optical (Tokyo, Japan) microscope, a CCD camera (Hamamatsu, Shizouka, Japan), and a Lambda-LS xenon arc lamp light source (Sutter, Novato, CA). Cells were imaged at room temperature using Compix imaging systems and SimplePCI software (Compix, Cranberry, PA) at excitation wavelengths of $340 / 380 \mathrm{~nm}$ at a rate of 1 frame/3 s before and during the application of 1 $\mu \mathrm{g} / \mathrm{ml}$ LPS.

\section{Statistical analyses}

Statistical significance was assessed by two-tailed Student's $t$-test. $P$ values of $\leq 0.05$ were considered to be statistically significant.

\section{RESULTS}

\section{Human crypt IECs coexpress TLR1, TLR2, and TLR4}

Functional TLR2, TLR3, TLR4, and TLR5 gene products are expressed in IEC lines, but the distribution of TLRs in primary human IECs is more controversial. Therefore, the expression of TLR1-TLR5 was determined in the human intestinal epithelium by immunohistochemistry using intestinal specimens derived from surgical resections. Specific polyclonal antibodies to human TLR1, TLR2, TLR3, TLR4, and TLR5 were used in these experiments. A crypt cell demonstrating strong immunoreactivity for the combination of TLR1 (Fig. 1, $A-C$ ), TLR2 (Figs. 1, $A$ and $C$, and 2), and TLR4 (Fig. $1 B$ ) was identified in the uninflamed ileum $(n=5$ of 5 specimens; Supplemental Fig. $1 C)$ and colon $(n=9$ of 9 specimens; Figs. 1-3). ${ }^{1}$ TLR-expressing cells were almost exclusively located in the crypts (2-5 cells/crypt). Colocalization of TLR1 with TLR2 (Fig. 1, $A$ and $C$ ) and TLR1 with TLR4 (Fig. 1B) immunoreactivity were demonstrated by fluorescent double labeling. No immunoreactivity was observed with an antibody to TLR3 or TLR5 in IECs or in the lamina propria (data not shown). TLR1-, TLR2-, and TLR4-stained IECs were observed in experiments performed on paraffin-embedded sections (Figs. 1 and 2) following antigen recovery and on frozen sections (Supplemental Fig. 1D). Immunoreactivity for TLR1, TLR2, and TLR4 was specific, as staining was not detected with species- and isotypematched control primary antibodies (Supplemental Fig. 1, $A$ and $B$ ), and identical immunostaining patterns were demonstrated using fluorescent (Figs. 1-3) and alkaline phosphatase (Supplemental Fig. 1, $C$ and $D$ )-labeled secondary antibodies. Moreover, to confirm specificity of immunostaining, different secondary antibodies were used for TLR detection [TLR1: anti-goat FITC (Fig. 1A) and TLR1-biotin, streptavidin-phycoerythrin (PE) (Fig. 1B); TLR2: anti-goat FITC (Fig. 1A) and anti-goat PE (Fig. 2)]. Importantly, TLR1 (Supplemental Fig. 1A) and TLR2 (Supplemental Fig. 1B) immunoreactivity were

\footnotetext{
${ }^{1}$ Supplemental data for this article is available online at the American Journal of Physiology-Gastrointestinal and Liver Physiology website.
} 
abrogated by preincubating the respective antibody with specific blocking peptides. As final specificity controls, antibodies for TLR1, TLR2, and TLR4 detected their respective human receptor expressed in transfected HEK-293T cells by immunohistochemistry, but did not cross react with other TLR family members (Supplemental Fig. 2). Furthermore, specific human antibodies detected transfected TLR 2 and endogenous TLR 1 of the expected size by Western immunoblot/coimmunoprecipitation in HEK-293T cells and immunoprecipitated endogenous TLR4 in the enteroendocrine IEC line BON (Supplemental Fig. 3).

In the lamina propria of intestinal tissue sections, TLR immunoreactivity of cells morphologically consistent with macrophages was present. However, the intensity of staining was much lower than the crypt epithelial cells (Figs. 1 and 2 and Supplemental Fig. 1). No other cells in the epithelium appearred to stain with anti-TLR1, anti-TLF2, antiTLF3, anti-TLF4, and anti-TLF5 antibodies, but this finding does not exclude the possibility of low-level TLR expression and immunoreactivity of other IEC populations (Figs. 1 and 2 and Supplemental Figs. 1 and 2).

\section{TLR expression in IECs colocalizes with the enteroendocrine marker serotonin}

To further morphologically characterize IECs that express TLRs, costaining experiments were performed with TLR antibodies and a monoclonal antibody to an epithelial cell marker, multicytokeratin. Colocalization of TLR2 immunoreactivity with NCL-C11 confirmred that these cells were, in fact, IECs (Fig. 2). IECs expressing TLRs are morphologically different from conventional absorptive epithelial, goblet, and Paneth cells. They have features reminiscent of the enteroendocrine lineage, including a pyramidal shape with a large basolateral surface, an apically displaced nucleus, and a granular appearance. To determine whether the IECs immunoreactive for TLR1, TLR2, and TLR4 were EECs, immunohistochemistry was performed with a polyclonal antibody to serotonin. Serotonin expression was detected in uninflamed human ileal and colonic sections, and serotonin immunoreactivity colocalized with TLR1 staining (Fig. 3A) and TLR2 (Fig. 3B). Identical immunostaining patterns were observed in murine colonic sections using anti-TLR antibodies cross reactive to murine TLR2 (Fig. 4A), TLR6 (Fig. 4B), and TLR4 (data not shown) that colocalize with serotonin immunoreactivity. Thus, an IEC that expresses a combination of TLRs represents a highly differentiated population and belongs to the enteroendocrine lineage. The characterization and distribution of these TLR-expressing epithelial cells suggest that they represent a novel population of IECs with a potential role in innate immune responses in the intestinal mucosa.

\section{EEC lines express TLRs}

To begin to determine functional consequences of TLR expression by EECs, the presence of TLRs in intestine-derived EEC lines was determined. The murine EEC line STC-1 (38) expresses mRNA transcripts for TLR1, TLR2, TLR4, TLR6, and the TLR4 coreceptor MD2 (Fig. 5A). The RAW264.7 murine macrophage cell line was used as a positive control for TLR expression. Compared with RAW264.7 cells, STC-1 cells expressed qualitatively lower levels of TLR mRNA. Furthermore, STC-1 cells expressed TLR2 (Fig. 5C), the TLR4/MD2 complex (Fig. 5D), and TLR6 (Fig. 5E) protein. Thus, the STC-1 EEC line expresses the same repertoire of TLRs observed in primary human and murine EECs.

\section{TLR ligands activate NF-KB and MAPK pathways in STC-1 cells}

Activation of the NF- $\kappa \mathrm{B}$ family of transcription factors is a central downstream signaling event in TLR-mediated cellular activation and regulates gene expression in many cell types. To determine whether TLR expression on EECs is functional, STC-1 cells were transiently transfected with a NF- $\kappa \mathrm{B}$ luciferase reporter plasmid and stimulated with the TLR4 ligand LPS or the TLR1/TLR2 ligand sBLP. STC-1 cells demonstrated a dose-dependent 
transcriptional activation of the NF- $\mathrm{KB}$ reporter to TLR ligands (Fig. 6). The activation of MAPK is another important signaling event in TLR-mediated responses. Accordingly, STC-1 cells were stimulated with LPS or SBLP to assess MAPK activation. Phosphorylation of ERK1/2 MAPK was detected as early as 2 min (Fig. 7). These experimental results support the presence of an intact intracellular signal transduction pathway downstream of TLRs, leading to NF- $\mathrm{KB}$ and MAPK activation in EECs.

\section{TLR ligands induce cytokine and chemokine expression in STC-1 cells}

Absorptive enterocytes participate in innate immune responses through the elaboration of cytokines such as TNF and chemokines like IL-8 when activated by pathogenic bacteria through TLRs. Whether EECs are programmed for similar responses is unknown. STC-1 cells were stimulated with LPS or sBLP. MIP-2 (the murine homologue of human IL-8) and TNF expression was evaluated by RT-PCR (Fig. 8A). TLR ligands induced rapid accumulation of MIP-2 mRNA, which was detected after $2 \mathrm{~h}$ with maximal expression after $4 \mathrm{~h}$ of stimulation. Kinetics for TNF mRNA induction showed maximal levels between 2 and $4 \mathrm{~h}$ and slowly returned to baseline levels at the end of $8 \mathrm{~h}$ for each TLR ligand (data not shown). Likewise, LPS and sBLP induced concentration dependent secretion of MIP-2 (Fig. 8, $B$ and $C$ ) and TNF (Fig. 8, $D$ and $E$ ) protein that remain elevated after $96 \mathrm{~h}$ (data not shown).

\section{LPS induces TGF- $\beta$ in STC-1 cells}

IECs also secrete factors that inhibit immune responses and may serve to maintain mucosal homeostasis in vivo. TGF- $\beta$ is a regulatory cytokine constitutively expressed in freshly isolated IECs, with increased mRNA expression detected toward the base of the crypts (22). The relevant source among primary IECs remains to be determined, although TGF- $\beta$ protein is produced in both the small intestine and colon (25). TGF- $\beta$ is involved in oral tolerance (47), inhibits T and B cell proliferation, and antagonizes macrophage activation (24). In unstimulated STC- 1 cells, basal expression of TGF- $\beta$ mRNA was detected (Fig. 9A). Upon stimulation with LPS, maximal expression was induced at $4 \mathrm{~h}$. Supernatants were also analyzed for TGF- $\beta$ protein over $72 \mathrm{~h}$. An increase in the spontaneous secretion of TGF- $\beta$ in unstimulated samples was observed from 24 to $72 \mathrm{~h}$. Additionally, a dose-dependent increase of TGF- $\beta$ protein over the baseline amounts was detected in LPS-activated STC- 1 cells (Fig. 9B). To further support a role for TLR activation in TGF- $\beta$ expression, STC-1 cells were transfected with a constitutively active TLR4 expression plasmid (29), which induced TGF- $\beta$ secretion in an LPS-independent, concentration-dependent manner (Fig. $9 C$ ). Expression of pro- and anti-inflammatory molecules by an EEC line suggests that TLRs expressed on EECs may contribute to innate immune responses and mucosal homeostasis.

\section{LPS induces calcium flux in STC-1 cells}

One of the identifying characteristics of EECs is the presence of preformed storage vesicles that contain numerous bioactive compounds with hormonal and neurotransmitter properties. Calcium fluxes are associated with fusion events of storage vesicles $(3,48)$ and have been previously described in EECs stimulated with fatty acids $(15,52)$. To determine whether bacterial ligands caused calcium fluxes, STC-1 cells were loaded with fura- 2 and challenged with LPS or vehicle (PBS) (Fig. 10). After the introduction of LPS, there was an increase in the 340-to-380-nm ratio, indicating an increase in intracellular calcium. Levels retruned toward resting baseline but remained elevated out to $10 \mathrm{~min}$. When PBS vehicle was added, no perturbation in the 360-to-380-nm ratio was detected. As controls, RAW264.7 macrophages and Caco-2 cells, which express functional TLR4, did not demonstrate calcium flux (data not shown) in the presence of LPS. We speculate that increased intracellular 
calcium following TLR ligation leads to degranulation of EEC vesicles, suggesting a specialized function for TLR signaling in this cell type.

\section{LPS induces rapid secretion of CCK from STC-1 cells}

We next addressed whether TLR activation may induce degranulation of EEC vesicles and secretion of neurohormones. STC-1 cells were stimulated with LPS, SBLP, and BBS as a positive control, and supernatants assayed for CCK (Fig. 11). LPS, but not sBLP, induced a similar percent increase in CCK secretion as BBS, with slightly earlier kinetics (maximal increase in release at $30 \mathrm{~min}$ compared with $60 \mathrm{~min}$ for BBS; Fig. 11A, open bars). Furthermore, LPS- and BBS-stimulated CCK release is dependent on calcium, as preincubation with the calcium chelator BAPTA-AM significantly reduced CCK release (Fig. 11, $A$ and $C$, filled bars).

\section{STC-1 conditioned media inhibits LPS-activated macrophages}

Neurohormones produced by EECs and other cells, such as somatostatin and CCK, have been demonstrated to inhibit immune responses. $(1,7,8,12,31)$. Resident lamina propria macrophages are notably deficient in the expression of innate immune receptors and, therefore, do not produce proinflammatory cytokines when stimulated by bacterial ligands (44). Therefore, we explored the possibility that EECs may be involved in the downregulation of innate immune responses in macrophages. Conditioned media obtained from 4-day STC-1 cultures were transferred onto RAW264.7 cells, which were then stimulated with LPS for $24 \mathrm{~h}$. EEC supernatants inhibited NO production in LPS-stimulated RAW264.7 cells (Fig. 12A). This inhibitory activity was concentration dependent, as incremental inhibition of NO was demonstrated with $20-100 \%$ conditioned media (data not shown). In contrast, 4-day conditioned media from the IEC line Caco-2 and HEK-293T cells did not inhibit NO production in LPS-activated RAW264.7 cells. Cell viability was assayed by trypan blue exclusion, which was $\geq 90 \%$ in each condition. Furthermore, STC- 1 conditioned media inhibited NO production and IL-12 p40 protein expression in LPSactivated murine peritoneal (Fig. 12, $B$ and $C$ ) and BM-derived macrophages (Fig. 12, $D$ and $E$ ). To begin to determine the components of STC-1 conditioned media that may have immunoinhibitory properties, experiments with candidate molecules were performed. The EEC products serotonin, somatostatin, and CCK did not inhibit LPS-induced IL-12 p40 or $\mathrm{NO}$ in murine BM-derived or peritoneal macrophages (data not shown). However, TGF- $\beta$ inhibited LPS-activated NO (Fig. 13A) and IL-12 p40 (Fig. 13B) production in murine macrophages, suggesting that this growth factor, in part, mediates the inhibition of macrophage activation.

\section{DISCUSSION}

In this study, we showed that a subset of human and murine IECs coexpresses TLRs and belongs to the enteroendocrine lineage. Using an EEC line model, a broad range of functional effects of TLR activation was demonstrated, including NF- $\mathrm{kB}$ and MAPK activation, calcium fluxes and CCK secretion, and pro- and anti-inflammatory gene expression. Taken together, this study proposes a novel role for EECs as participants in mucosal innate immune responses and raises the hypothesis that EEC-bacterial interactions help to maintain intestinal immune homeostasis.

Previous immunohistochemical analyses of TLR expression in the human intestinal mucosa revealed different interpretations from our study $(2,5,6,13,14,30,32,35,49)$. These seemingly discrepant results may have several explanations. First, different antibodies were used in these studies. The use of different antibodies may have resulted in qualitatively different, but not necessarily mutually exclusive, staining patterns. We performed numerous 
controls to demonstrate the specificity of our immunohistochemical analysis. Second, our staining for TLR2 and TLR4 may have been more sensitive, enabling the detection of TLR2- and TLR4-expressing IECs that were not noted in the previous studies. Another report (34) first described the immunohistochemical expression of TLR4 on a murine IEC line and on the isolated murine intestinal crypt epithelium. In this well-controlled analysis, staining of the crypt appeared to be diffuse, suggesting that cells of the enteroendocrine lineage as well as other IEC types in the mouse may express TLR4 (19). Our study does not exclude the possibility that TLRs are expressed on other IEC types in lower quantities. Furthermore, this analysis was limited to the first five members of the TLR family. It is certainly possible that EECs and other IECs express other TLR family members.

In the present study, a specific crypt epithelial cell morphologically different from conventional absorptive epithelium coexpressed TLRs and was identified as a serotoninpositive EEC (Figs. 1-3). EECs represent $<1 \%$ of terminally differentiated cells in the intestinal mucosa. The intestinal epithelium harbors at least 15 types of EECs that have been characterized based on morphological criteria, the nature of their principal secretory product, specific marker molecules, and their ability to express certain transgenes $(39,40,43)$. Serotonin-expressing cells represent the largest population, can be detected throughout the whole intestine, and can be located in the crypt as well as along the villus $(17,41,43)$. Therefore, TLR-expressing IECs likely represent a distinct subpopulation of EECs.

Immune function associated with EECs is largely unknown. However, bacterial interactions with EECs have been described: for example, cholera toxin (a secretory enterotoxin produced by Vibrio cholerae) evokes intestinal fluid secretion via binding to its receptor GM1 ganglioside on EECs, followed by serotonin release and activation of the enteric nervous system $(10,50)$. Furthermore, the EEC product CCK has been described to be elevated in an acute upper gastrointestinal infection with Giardia and prevents bacterial translocation $(23,51)$. There have been few reports directly implicating the EEC in immune responses. One study (55) described a close proximity between EECs and T lymphocytes in the nonhuman primate gut mucosa, indirectly suggesting a functional interaction.

Additionally, colitis-prone $\mathrm{T}$ cell receptor- $\alpha$-deficient mice were demonstrated to have a decrease in the number of colonic EECs compared with age- and strain-matched controls (42), suggesting that EECs may possess homeostatic functions. Perhaps the most intriguing observation suggesting a role for bacterial interactions with EECs in human disease is the description of increased EEC cells following acute bacillary enteritis and in postdysenteric IBS $(36,45,46)$.

EECs are activated by nervous stimulation and discharge their secretions into the blood flowing through the villus capillary bed. This allows for stored peptides and secreted proteins to appear immediately at the tissue-blood interface, where it may exert an effect on leukocyte and monocyte recruitment. If this is the case, it suggests a role for EECs as highly specialized "lifeguards" of the intestinal mucosa with the capacity for early recognition of bacterial invasion with consequent recruitment of protective mechanisms mediated by the enteric immune and nervous systems. Here, we report that TLR activation in an EEC line was associated with a rapid calcium flux. It has been shown that exocytosis of secretory granules requires membrane fusion, a calcium-dependent process $(3,48)$. We further showed that CCK, an EEC product, was released in response to TLR signaling, perhaps through activation of the MAPK signaling pathway (33). Although mobilization of intracellular calcium is not a well-described downstream event of TLR activation, degranulation of secre-tory products in response to TLR signaling has been previously described in mast cells (26). We speculate that this may be a specific adaptation of EECs with consequent release of enteric neurohormones from secretory vesicles in response to TLR activation. 
Various neuropeptides expressed and released by EECs have been shown to inhibit immune responses. For example, somatostatin inhibits bacteria-induced IL-8 in IECs (7), and CCK inhibits LPS-mediated responses $(8,31)$. To date, we have not identified all of the potential bioactive components that inhibit macrophage activation in STC-1 conditioned media. In preliminary analyses, we have tested several described EEC products to determine whether they may mediate this inhibitory activity. Incubation of RAW264.7 cells and BM-derived macrophages with serotonin, somatostatin, or CCK did not inhibit NO or IL-12 p40 expression. We were interested in the observation that TGF- $\beta$ is upregulated in LPSactivated STC-1 cells given its well-described immunoregulatory functions $(24,47)$ and its role in wound healing (4). TGF- $\beta$ inhibited NO in BM-derived macrophages and IL-12 p40 expression in peritoneal macrophages (Fig. 13). Therefore, TGF- $\beta$ may partially mediate the inhibitory effect of STC-1 conditioned media.

A pivotal report further examined the importance of TLRs in the intestines. Mice deficient in TLR2, TLR4, or the signaling molecule MyD88 demonstrated increased severity of dextran sodium sulfate (DSS)-induced colitis and decreased survival compared with control mice (37), demonstrating that engagement of TLRs through recognition of ligands on commensal bacteria plays a beneficial role in intestinal homeostasis. This study is consistent with hypotheses raised by our findings: EECs express TLRs and actively produce factors, such as TGF- $\beta$, which may contribute to intestinal homeostasis and protection from epithelial damage. Constitutive expression of TLRs suggests that EECs may actively recognize bacteria even under normal physiological circumstances and contribute to the normal immunosuppressive state in the intestine.

Another possible consequence of TLR ligation in EECs is the production of the neutrophil attractant human IL-8 or murine MIP-2, used in our study as a readout in an EEC line model system. The intestinal epithelium, through the production of chemotactic factors, initiates the recruitment of immune cells to the lamina propria at sites of infection. Consequently, reduced numbers of neutrophils were observed in the lamina propria of TLR4- and MyD88deficient mice treated with DSS (11).

That TLR-expressing IECs belong to the enteroendocrine lineage raises intriguing hypotheses about how bacterial interactions regulate physiological and pathological inflammation. Multiple effects of TLR activation were demonstrated in a murine EEC line, but another caveat to this study is that there may be functional differences in TLR activation between mice and humans. However, the striking similarity in immunostaining patterns in EECs observed between species may suggest a conserved functional role. To fully understand the functional consequences of TLR expression on EECs will necessitate much more investigation, combining cell line and descriptive data with mouse models of mucosal immunity and inflammation.

\title{
Supplementary Material
}

Refer to Web version on PubMed Central for supplementary material.

\section{Acknowledgments}

\author{
GRANTS
}

This work was supported by National Institutes of Health Grants DK-54452 (to S. E. Plevy), AI-23504 (to L. F. Mayer), AI-24671 (to L. F. Mayer), AI-44236 (to L. F. Mayer), and F30-ES-013617 (to S. H. Davé); a Crohn's and Colitis Foundation of America (CCFA) Senior Research Award (to S. E. Plevy); and a CCFA Research Fellowship Award (to M. Bogunovic). 


\section{REFERENCES}

1. Abad C, Martinez C, Juarranz MG, Arranz A, Leceta J, Delgado M, Gomariz RP. Therapeutic effects of vasoactive intestinal peptide in the trinitrobenzene sulfonic acid mice model of Crohn's disease. Gastroenterology. 2003; 124:961-971. [PubMed: 12671893]

2. Abreu MT, Vora P, Faure E, Thomas LS, Arnold ET, Arditi M. Decreased expression of Toll-like receptor-4 and MD-2 correlates with intestinal epithelial cell protection against dysregulated proinflammatory gene expression in response to bacterial lipopolysaccharide. J Immunol. 2001; 167:1609-1616. [PubMed: 11466383]

3. Barg S. Mechanisms of exocytosis in insulin-secreting B-cells and glucagon-secreting A-cells. Pharmacol Toxicol. 2003; 92:3-13. [PubMed: 12710591]

4. Beck PL, Rosenberg IM, Xavier RJ, Koh T, Wong JF, Podolsky DK. Transforming growth factorbeta mediates intestinal healing and susceptibility to injury in vitro and in vivo through epithelial cells. Am J Pathol. 2003; 162:597-608. [PubMed: 12547717]

5. Cario E, Podolsky DK. Differential alteration in intestinal epithelial cell expression of toll-like receptor 3 (TLR3) and TLR4 in inflammatory bowel disease. Infect Immun. 2000; 68:7010-7017. [PubMed: 11083826]

6. Cario E, Rosenberg IM, Brandwein SL, Beck PL, Reinecker HC, Podolsky DK. Lipopolysaccharide activates distinct signaling pathways in intestinal epithelial cell lines expressing Toll-like receptors. J Immunol. 2000; 164:966-972. [PubMed: 10623846]

7. Chowers Y, Cahalon L, Lahav M, Schor H, Tal R, Bar-Meir S, Levite M. Somatostatin through its specific receptor inhibits spontaneous and TNF-alpha- and bacteria-induced IL-8 and IL-1 beta secretion from intestinal epithelial cells. J Immunol. 2000; 165:2955-2961. [PubMed: 10975802]

8. Cong B, Li SJ, Yao YX, Zhu GJ, Ling YL. Effect of cholecystokinin octapeptide on tumor necrosis factor alpha transcription and nuclear factor-kappaB activity induced by lipopolysaccharide in rat pulmonary interstitial macrophages. World J Gastroenterol. 2002; 8:718-723. [PubMed: 12174385]

9. Eckmann L, Jung HC, Schurer-Maly C, Panja A, Morzycka-Wroblewska E, Kagnoff MF. Differential cytokine expression by human intestinal epithelial cell lines: regulated expression of interleukin 8. Gastroenterology. 1993; 105:1689-1697. [PubMed: 8253345]

10. Farthing MJ. Enterotoxins and the enteric nervous system-a fatal attraction. Int J Med Microbiol. 2000; 290:491-496. [PubMed: 11111932]

11. Fukata M, Michelsen KS, Eri R, Thomas LS, Hu B, Lukasek K, Nast CC, Lechago J, Xu R, Naiki Y, Soliman A, Arditi M, Abreu MT. Toll-like receptor-4 is required for intestinal response to epithelial injury and limiting bacterial translocation in a murine model of acute colitis. Am J Physiol Gastrointest Liver Physiol. 2005; 288:G1055-G1065. [PubMed: 15826931]

12. Ganea D, Delgado M. Vasoactive intestinal peptide (VIP) and pituitary adenylate cyclaseactivating polypeptide (PACAP) as modulators of both innate and adaptive immunity. Crit Rev Oral Biol Med. 2002; 13:229-237. [PubMed: 12090463]

13. Gewirtz AT, Navas TA, Lyons S, Godowski PJ, Madara JL. Cutting edge: bacterial flagellin activates basolaterally expressed TLR5 to induce epithelial proinflammatory gene expression. J Immunol. 2001; 167:1882-1885. [PubMed: 11489966]

14. Hausmann M, Kiessling S, Mestermann S, Webb G, Spottl T, Andus T, Scholmerich J, Herfarth H, Ray K, Falk W, Rogler G. Toll-like receptors 2 and 4 are up-regulated during intestinal inflammation. Gastroenterology. 2002; 122:1987-2000. [PubMed: 12055604]

15. Hira T, Elliott AC, Thompson DG, Case RM, McLaughlin JT. Multiple fatty acid sensing mechanisms operate in enteroendocrine cells: novel evidence for direct mobilization of stored calcium by cytosolic fatty acid. J Biol Chem. 2004; 279:26082-26089. [PubMed: 15066999]

16. Hirschfeld M, Ma Y, Weis JH, Vogel SN, Weis JJ. Cutting edge: repurification of lipopolysaccharide eliminates signaling through both human and murine toll-like receptor 2. J Immunol. 2000; 165:618-622. [PubMed: 10878331]

17. Hocker M, Wiedenmann B. Molecular mechanisms of enteroendocrine differentiation. Ann NY Acad Sci. 1998; 859:160-174. [PubMed: 9928379]

18. Hoffmann JA, Kafatos FC, Janeway CA, Ezekowitz RA. Phylogenetic perspectives in innate immunity. Science. 1999; 284:1313-1318. [PubMed: 10334979] 
19. Hornef MW, Frisan T, Vandewalle A, Normark S, Richter-Dahlfors A. Toll-like receptor 4 resides in the Golgi apparatus and colocalizes with internalized lipopolysaccharide in intestinal epithelial cells. J Exp Med. 2002; 195:559-570. [PubMed: 11877479]

20. Jung HC, Eckmann L, Yang SK, Panja A, Fierer J, Morzycka-Wroblewska E, Kagnoff MF. A distinct array of proinflammatory cytokines is expressed in human colon epithelial cells in response to bacterial invasion. J Clin Invest. 1995; 95:55-65. [PubMed: 7814646]

21. Kagnoff MF, Eckmann L. Epithelial cells as sensors for microbial infection. J Clin Invest. 1997; 100:6-10. [PubMed: 9202050]

22. Koyama SY, Podolsky DK. Differential expression of transforming growth factors alpha and beta in rat intestinal epithelial cells. J Clin Invest. 1989; 83:1768-1773. [PubMed: 2708531]

23. Leslie FC, Thompson DG, McLaughlin JT, Varro A, Dockray GJ, Mandal BK. Plasma cholecystokinin concentrations are elevated in acute upper gastrointestinal infections. QJM. 2003; 96:870-871. [PubMed: 14566044]

24. Letterio JJ, Roberts AB. Regulation of immune responses by TGF-beta. Annu Rev Immunol. 1998; 16:137-161. [PubMed: 9597127]

25. Lugering N, Kucharzik T, Gockel H, Sorg C, Stoll R, Domschke W. Human intestinal epithelial cells down-regulate IL-8 expression in human intestinal microvascular endothelial cells; role of transforming growth factor-beta 1 (TGF-beta1). Clin Exp Immunol. 1998; 114:377-384. [PubMed: 9844046]

26. McCurdy JD, Olynych TJ, Maher LH, Marshall JS. Cutting edge: distinct Toll-like receptor 2 activators selectively induce different classes of mediator production from human mast cells. $\mathbf{J}$ Immunol. 2003; 170:1625-1629. [PubMed: 12574323]

27. Medzhitov R. Toll-like receptors and innate immunity. Nat Rev Immunol. 2001; 1:135-145. [PubMed: 11905821]

28. Medzhitov R, Janeway CA Jr. An ancient system of host defense. Curr Opin Immunol. 1998; 10:12-15. [PubMed: 9523104]

29. Medzhitov R, Preston-Hurlburt P, Janeway CA Jr. A human homologue of the Drosophila Toll protein signals activation of adaptive immunity. Nature. 1997; 388:394-397. [PubMed: 9237759]

30. Melmed G, Thomas LS, Lee N, Tesfay SY, Lukasek K, Michelsen KS, Zhou Y, Hu B, Arditi M, Abreu MT. Human intestinal epithelial cells are broadly unresponsive to Toll-like receptor 2dependent bacterial ligands: implications for host-microbial interactions in the gut. J Immunol. 2003; 170:1406-1415. [PubMed: 12538701]

31. Meng AH, Ling YL, Zhang XP, Zhang JL. Anti-inflammatory effect of cholecystokinin and its signal transduction mechanism in endotoxic shock rat. World J Gastroenterol. 2002; 8:712-717. [PubMed: 12174384]

32. Naik S, Kelly EJ, Meijer L, Pettersson S, Sanderson IR. Absence of Toll-like receptor 4 explains endotoxin hyporesponsiveness in human intestinal epithelium. J Pediatr Gastroenterol Nutr. 2001; 32:449-453. [PubMed: 11396812]

33. Nemoz-Gaillard E, Cordier-Bussat M, Filloux C, Cuber JC, Van Obberghen E, Chayvialle JA, Abello J. Bombesin stimulates cholecystokinin secretion through mitogen-activated proteinkinase-dependent and -independent mechanisms in the enteroendocrine STC-1 cell line. Biochem J. 1998; 331:129-135. [PubMed: 9512470]

34. Ortega-Cava CF, Ishihara S, Rumi MA, Kawashima K, Ishimura N, Kazumori H, Udagawa J, Kadowaki Y, Kinoshita Y. Strategic compartmentalization of Toll-like receptor 4 in the mouse gut. J Immunol. 2003; 170:3977-3985. [PubMed: 12682225]

35. Otte JM, Cario E, Podolsky DK. Mechanisms of cross hyporesponsiveness to Toll-like receptor bacterial ligands in intestinal epithelial cells. Gastroenterology. 2004; 126:1054-1070. [PubMed: 15057745]

36. Park JH, Rhee PL, Kim G, Lee JH, Kim YH, Kim JJ, Rhee JC, Song SY. Enteroendocrine cell counts correlate with visceral hypersensitivity in patients with diarrhoea-predominant irritable bowel syndrome. Neurogastroenterol Motil. 2006; 18:539-546. [PubMed: 16771769]

37. Rakoff-Nahoum S, Paglino J, Eslami-Varzaneh F, Edberg S, Medzhitov R. Recognition of commensal microflora by toll-like receptors is required for intestinal homeostasis. Cell. 2004; 118:229-241. [PubMed: 15260992] 
38. Rindi G, Grant SG, Yiangou Y, Ghatei MA, Bloom SR, Bautch VL, Solcia E, Polak JM. Development of neuroendocrine tumors in the gastrointestinal tract of transgenic mice. Heterogeneity of hormone expression. Am J Pathol. 1990; 136:1349-1363. [PubMed: 2162628]

39. Rindi G, Leiter AB, Kopin AS, Bordi C, Solcia E. The "normal" endocrine cell of the gut: changing concepts and new evidences. Ann NY Acad Sci. 2004; 1014:1-12. [PubMed: 15153415]

40. Roth KA, Gordon JI. Spatial differentiation of the intestinal epithelium: analysis of enteroendocrine cells containing immunoreactive serotonin, secretin, and substance $\mathrm{P}$ in normal and transgenic mice. Proc Natl Acad Sci USA. 1990; 87:6408-6412. [PubMed: 1696730]

41. Roth KA, Hertz JM, Gordon JI. Mapping enteroendocrine cell populations in transgenic mice reveals an unexpected degree of complexity in cellular differentiation within the gastrointestinal tract. J Cell Biol. 1990; 110:1791-1801. [PubMed: 2186049]

42. Rubin DC, Zhang H, Qian P, Lorenz RG, Hutton K, Peters MG. Altered enteroendocrine cell expression in T cell receptor alpha chain knock-out mice. Microsc Res Tech. 2000; 51:112-120. [PubMed: 11054861]

43. Sjolund K, Sanden G, Hakanson R, Sundler F. Endocrine cells in human intestine: an immunocytochemical study. Gastroenterology. 1983; 85:1120-1130. [PubMed: 6194039]

44. Smith PD, Ochsenbauer-Jambor C, Smythies LE. Intestinal macrophages: unique effector cells of the innate immune system. Immunol Rev. 2005; 206:149-159. [PubMed: 16048547]

45. Spiller RC. Postinfectious irritable bowel syndrome. Gastroenterology. 2003; 124:1662-1671. [PubMed: 12761724]

46. Spiller RC, Jenkins D, Thornley JP, Hebden JM, Wright T, Skinner M, Neal KR. Increased rectal mucosal enteroendocrine cells, T lymphocytes, and increased gut permeability following acute Campylobacter enteritis and in post-dysenteric irritable bowel syndrome. Gut. 2000; 47:804-811. [PubMed: 11076879]

47. Strober W, Kelsall B, Marth T. Oral tolerance. J Clin Immunol. 1998; 18:1-30. [PubMed: 9475350]

48. Sudhof TC. The synaptic vesicle cycle. Annu Rev Neurosci. 2004; 27:509-547. [PubMed: 15217342]

49. Suzuki M, Hisamatsu T, Podolsky DK. Gamma interferon augments the intracellular pathway for lipopolysaccharide (LPS) recognition in human intestinal epithelial cells through coordinated upregulation of LPS uptake and expression of the intracellular Toll-like receptor 4-MD-2 complex. Infect Immun. 2003; 71:3503-3511. [PubMed: 12761135]

50. Turvill JL, Mourad FH, Farthing MJ. Crucial role for 5-HT in cholera toxin but not Escherichia coli heat-labile enterotoxin-intestinal secretion in rats. Gastroenterology. 1998; 115:883-890. [PubMed: 9753491]

51. Wang X, Soltesz V, Axelson J, Andersson R. Cholecystokinin increases small intestinal motility and reduces enteric bacterial overgrowth and translocation in rats with surgically induced acute liver failure. Digestion. 1996; 57:67-72. [PubMed: 8626051]

52. Wang Y, Prpic V, Green GM, Reeve JR Jr, Liddle RA. Luminal CCK-releasing factor stimulates CCK release from human intestinal endocrine and STC-1 cells. Am J Physiol Gastrointest Liver Physiol. 2002; 282:G16-G22. [PubMed: 11751153]

53. Weinstein SL, Finn AJ, Dave SH, Meng F, Lowell CA, Sanghera JS, DeFranco AL. Phosphatidylinositol 3-kinase and mTOR mediate lipopolysaccharide-stimulated nitric oxide production in macrophages via interferon-beta. J Leukoc Biol. 2000; 67:405-414. [PubMed: 10733102]

54. Xiong H, Zhu C, Li F, Hegazi R, He K, Babyatsky M, Bauer AJ, Plevy SE. Inhibition of interleukin-12 p40 transcription and NF-kappaB activation by nitric oxide in murine macrophages and dendritic cells. J Biol Chem. 2004; 279:10776-10783. [PubMed: 14679201]

55. Yang GB, Lackner AA. Proximity between 5-HT secreting enteroendocrine cells and lymphocytes in the gut mucosa of rhesus macaques (Macaca mulatta) is suggestive of a role for enterochromaffin cell 5-HT in mucosal immunity. J Neuroimmunol. 2004; 146:46-49. [PubMed: 14698846] 
56. Zhu C, Gagnidze K, Gemberling JH, Plevy SE. Characterization of an activation protein-1-binding site in the murine interleukin-12 p40 promoter. Demonstration of novel functional elements by a reductionist approach. J Biol Chem. 2001; 276:18519-18528. [PubMed: 11279072] 
A

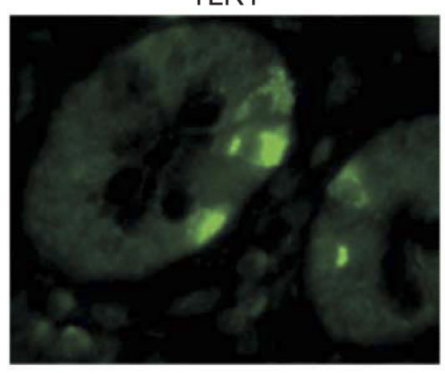

B

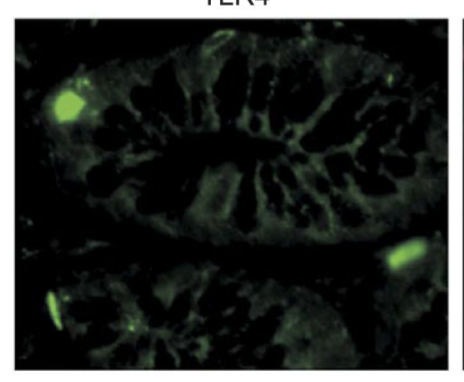

TLR2

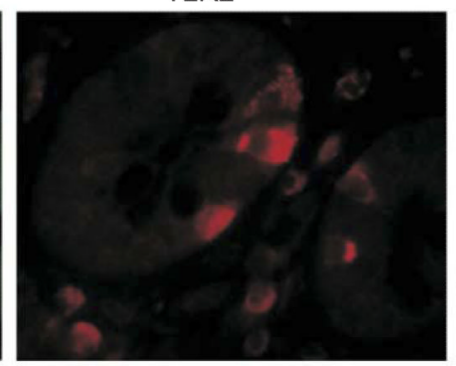

TLR1

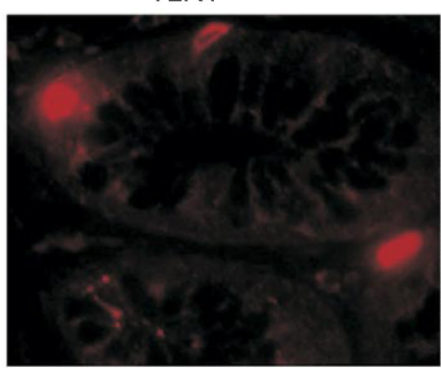

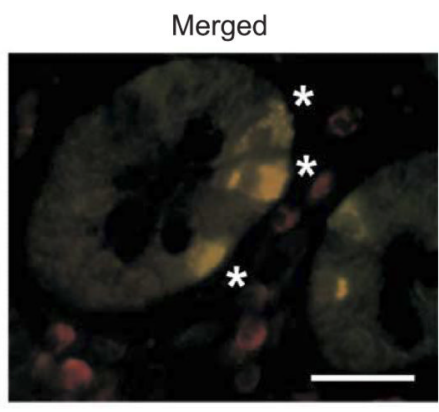

Merged

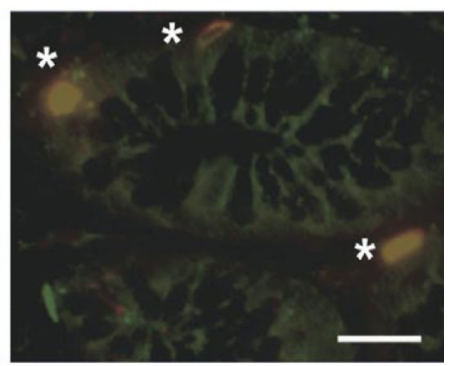

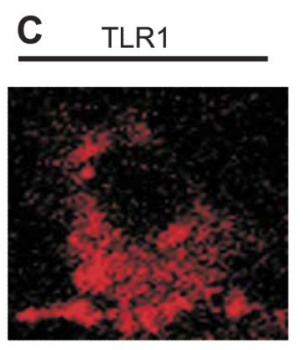

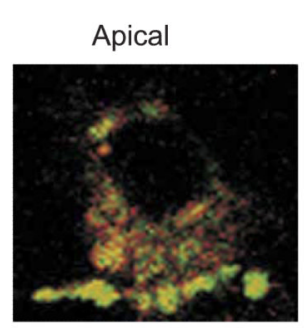

TLR2

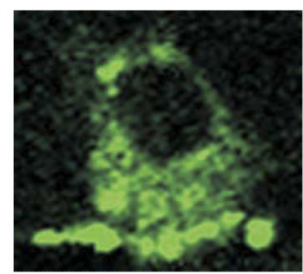

Basal

Fig. 1.

Toll-like receptor (TLR)1, TLR2, and TLR4 were coexpressed by a human intestinal epithelial cell (IEC) that mainly resides in the crypts. Paraffin-embedded tissue sections of the histologically normal human colon and ileum were immunostained with specific antibodies as described in detail in materials and methods $(A-C)$. $A$ : double-immunofluorescent staining of the colon with anti-TLR1 (FITC) and anti-TLR2 (Texas red) antibodies. Asterisks show TLR1 ${ }^{+}$TLR2 $^{+}$cells in the epithelial monolayer. $B$ : doubleimmunofluorescent staining of the colon with anti-TLR4 (FITC) and anti-TLR1 (Texas red) antibodies. Asterisks show TLR $1^{+} \mathrm{TLR}^{+}$cells in the epithelial monolayer. Magnification: $\times 400$. Scale bars $=50 \mu \mathrm{m}$. $C$ : double staining of the colon with anti-TLR1 (Texas red; left) and anti-TLR2 (FITC; right) antibodies and a superimposed image of both (middle). A single epithelial cell located in a crypt was visualized by confocal microscopy. 

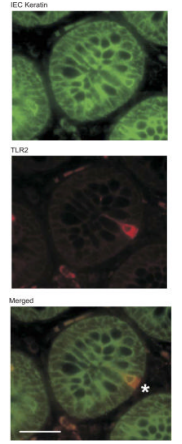

Fig. 2.

$\mathrm{TLR}^{+}$cells in the epithelial monolayer of the human colon express IEC-specific cytokeratins. Double staining of the colon with IEC-specific anti-multicytokeratin (FITC) and anti-TLR2 (Texas red) antibodies is shown. The asterisk shows a

$\mathrm{TLR}^{+}$multicytokeratin ${ }^{+}$cell in the intestinal crypt. Magnification: $\times 400$. Scale bar $=50 \mu \mathrm{m}$. 


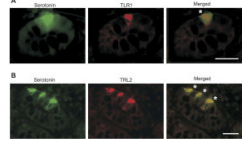

Fig. 3.

TLR-immunoreactive cells in human colonic specimens express an enteroendocrine cell (EEC) marker, serotonin. A: double staining of the colon with anti-serotonin (FITC) and anti-TLR1 (Texas red) antibodies. The asterisk shows a TLR $1^{+}$serotonin $^{+}$cell in the intestinal crypt. Magnification: $\times 400$. Scale bar $=50 \mu \mathrm{m} . B$ : double staining of the colon with anti-serotonin (FITC) and anti-TLR2 (Texas red) antibodies. Asterisks show

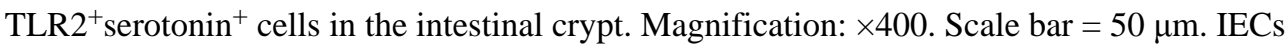
expressing TLRs have features reminiscent of an EEC lineage, including a pyramidal shape with a large basolateral surface, an apically displaced nucleus, and a granular appearance. 


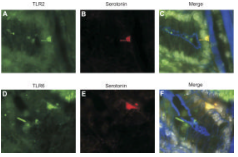

Fig. 4.

TLR-immunoreactive cells in murine colonic specimens express an EEC marker, serotonin. $A$ and $B$ : double staining of murine colonic sections with anti-TLR2 (Alexa488 secondary; $A$ ) and anti-serotonin (Cy3 secondary; $B$ ), an EEC marker. $C$ : superimposed image of $A$ and $B$ with nuclei depicted in white and actin in blue. $D$ and $E$ : double staining of murine colonic sections with anti-TLR6 (Alexa488 secondary; $D$ ) and anti-serotonin (Cy3 secondary; $E$ ). $F$ : superimposed image of $D$ and $E$ with nuclei depicted in white and actin in blue. 


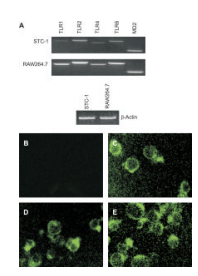

Fig. 5.

The murine EEC line STC-1 expresses TLRs. A, top: expressions of TLR and MD2 mRNA were analyzed by PCR of reverse-transcribed total RNA isolated from STC-1 cells. RNA isolated from RAW264.7 macrophage cells was used as a positive control. RT-PCR amplified $\beta$-actin mRNA is shown as a loading control (bottom). B-E: STC-1 cells were stained (FITC secondary) with control $\operatorname{IgG}(B)$, anti-TLR2 $(C)$, anti-TLR4/MD2 complex $(D)$, and anti-TLR6 antibodies $(E)$. Experiments were repeated 3 times, and a representative result is displayed. 

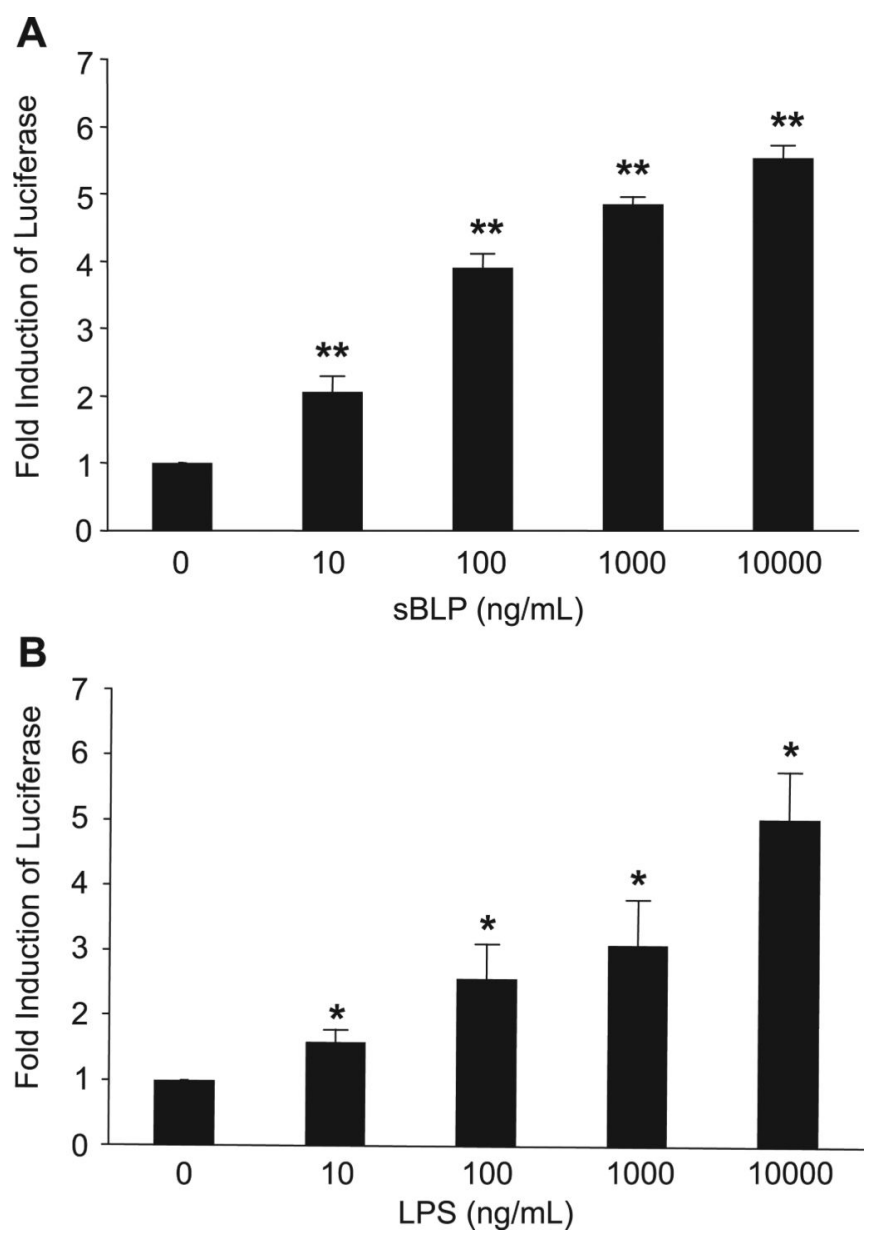

Fig. 6.

TLR1/2 [synthetic bacterial lipoprotein (sBLP)] and TLR4 (LPS) ligands activate NF- $\kappa$ B in the murine STC-1 EEC line. NF- $\kappa$ B activation was assessed by transient transfection of a plasmid with a multimerized NF- $\kappa \mathrm{B}$ DNA binding element luciferase reporter. $A$ and $B$ : STC- 1 cells were stimulated for $8 \mathrm{~h}$ with a dose titration of $\operatorname{sBLP}(A)$ or LPS $(B)$. Results are expressed as relative light units normalized to $\beta$-galactosidase activity from a cotransfected heat shock protein (HSP) promoter- $\beta$-galactosidase plasmid to correct for transfection efficiency. The fold induction of NF- $\mathrm{NB}$ luciferase was compared with values in unstimulated cells (equal to 1) for each group. Each result represents the mean \pm SD of 3-5 experiments. $* P<0.05$ and $* * P<0.005$ compared with unstimulated cells for each group. 


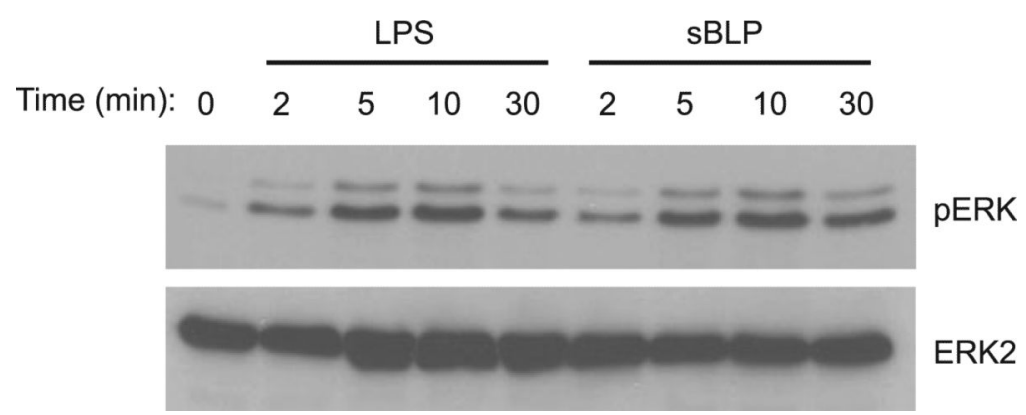

Fig. 7.

sBLP and LPS activate the ERK MAPK pathway in STC-1 cells. MAPK activation was assessed in cells stimulated with LPS or $\operatorname{sBLP}(10 \mu \mathrm{g} / \mathrm{ml})$ for $0,2,5,10$, or $30 \mathrm{~min}$. Whole cell extracts were isolated as described in mateRIaLs AND METHODs. Western blots were probed for phosphorylated (p)ERK1/2 and total ERK2 to determine equal loading. Experiments were repeated 3 times, and a representative result is displayed. 


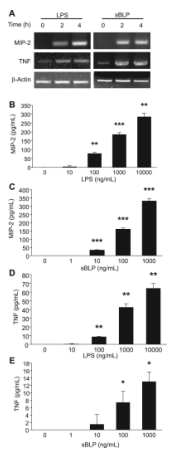

Fig. 8.

TLR ligands induce TNF and macrophage inhibitory protein (MIP)-2 mRNA and protein expression in STC-1 cells. STC-1 cells were stimulated with $10 \mu \mathrm{g} / \mathrm{ml}$ of LPS or sBLP for 0-4 h. A: cells were harvested via TRIzol. Total RNA was isolated, digested with DNase I, and subsequently reverse transcribed into cDNA. TNF, MIP-2, and $\beta$-actin PCR primer sequences are described in materials and methods. Experiments were repeated 3 times, and a representative result is displayed. $B-E$ : STC-1 cells were stimulated with increasing amounts of LPS $(B$ and $D)$ or sBLP $(C$ and $E$ ) for $48 \mathrm{~h}$. ELISA was performed on cell-free supernatants for MIP-2 $(B$ and $C$ ) and TNF ( $D$ and $E$ ). Experiments were performed in triplicate, and results represent means \pm SD. $* P<0.05$, $* * P<0.01$, and $* * * P<0.001$ compared with unstimulated cells for each group. 

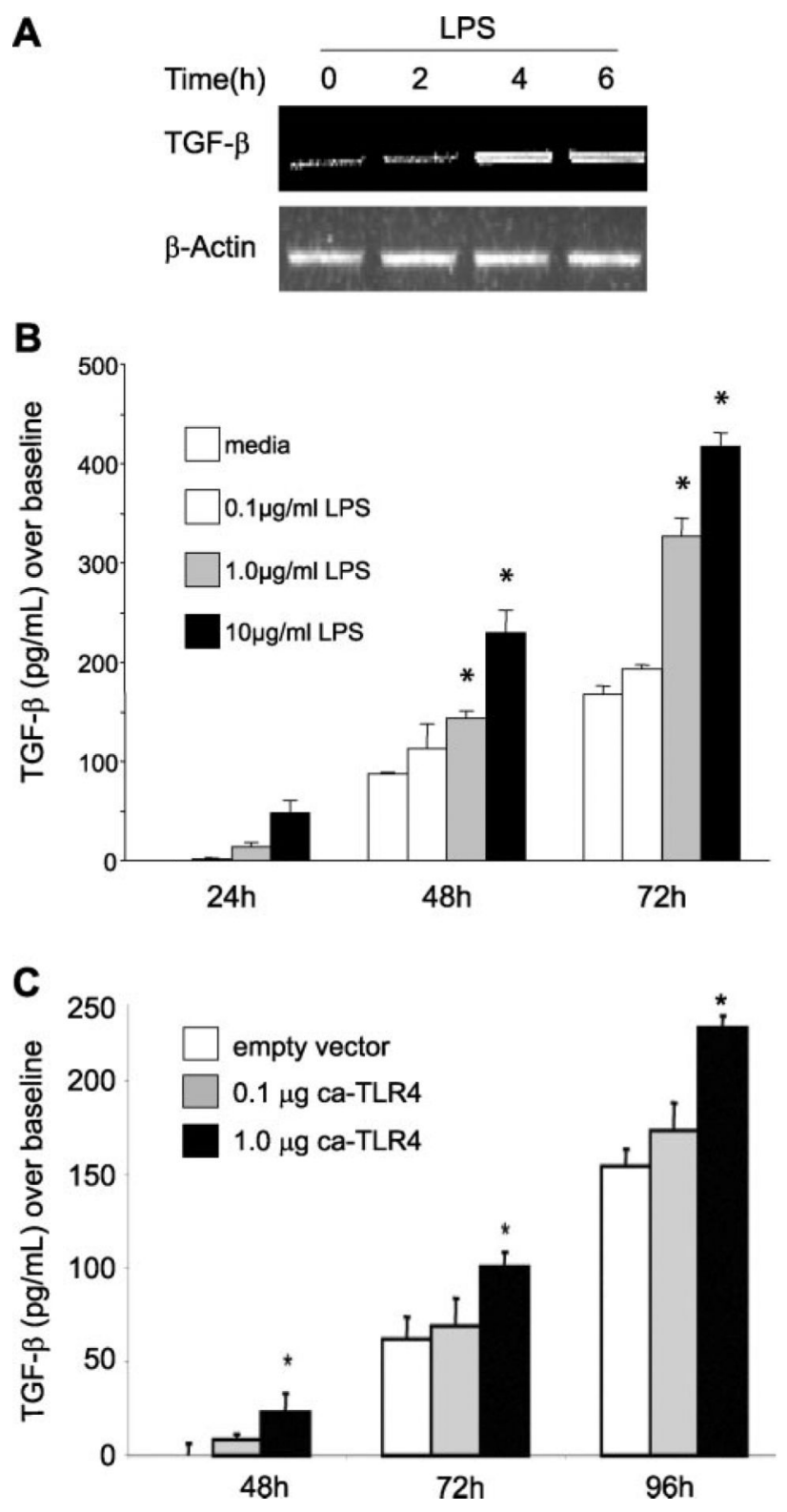

Fig. 9.

LPS and TLR4 induce transforming growth factor (TGF)- $\beta$ expression in STC- 1 cells. $A$ : STC- 1 cells were grown in $1 \%$ FBS and stimulated with $10 \mu \mathrm{g} / \mathrm{ml}$ LPS for $0-6 \mathrm{~h}$. Total RNA was isolated and reverse transcribed. TGF- $\beta$ and $\beta$-actin primer sequences are described in materials and methods. Experiments were repeated 3 times, and a representative result is displayed. $B$ : STC-1 cells were stimulated with $0.1-10 \mu \mathrm{g} / \mathrm{ml}$ LPS for 24,48 , or 72 h. ELISA was performed on the supernatants for TGF- $\beta$ according to the manufacturer's protocols. Experiments were performed in triplicate, and results represent means $\pm \mathrm{SD}$. ${ }^{*} P<$ 0.05 compared with unstimulated cells for each time group. $C$ : constitutively active (ca)TLR4 expression plasmid increased TGF- $\beta$ production in transfected STC-1 cells. STC- 1 cells were grown in $1 \% \mathrm{FBS}$ and transfected with a total of $1 \mu \mathrm{g}$ plasmid DNA (empty vector pcDNA3 + ca-TLR4). STC-1 cells were incubated for 48, 72, or $96 \mathrm{~h}$. ELISA was performed on the supernatants for TGF- $\beta$ according to the manufacturer's protocols. 
Experiments were performed in triplicate, and results represent means \pm SD. $* P<0.05$ compared with empty vector control for each time group. 


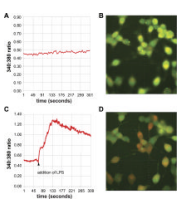

Fig. 10.

LPS induces a rapid calcium flux in STC-1 cells. STC-1 cells were loaded with fura-2 and incubated in DMEM with $10 \%$ FBS. $A$ and $B$ : cells were initially stabilized. $C$ and $D$ : cells were subsequently treated with $1 \mu \mathrm{g} / \mathrm{ml}$ LPS (addition of LPS), causing an increase in the internal calcium concentration. Experiments were performed in trip-licate, and a representative result is shown. 


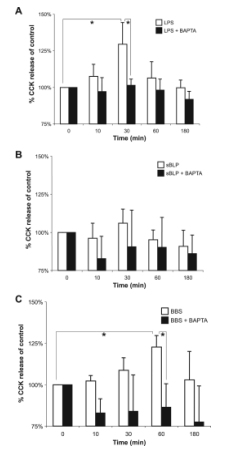

Fig. 11.

LPS induces secretion of CCK in STC-1 cells. Cells were pretreated in the presence or absence of the calcium chelator BAPTA-AM $(20 \mu \mathrm{M}) 30 \mathrm{~min}$ prior to being stimulated for $10,30,60$, and $180 \mathrm{~min}$ with $1 \mu \mathrm{g} / \mathrm{ml} \operatorname{LPS}(A), 10 \mu \mathrm{g} / \mathrm{ml} \mathrm{sBLP}(B)$, or $10 \mathrm{nM}$ bombesin $(\mathrm{BBS} ; C)$. Enzyme immunoassay was performed on cell-free supernatants for CCK.

Experiments were performed 4 times. Due to the variation of the baseline production of $\mathrm{CCK}$, results were normalized to controls (unstimulated) and presented as percentages of control values. The average (mean + SD) baseline production of CCK was $1.8 \pm 0.6 \mathrm{ng} / \mathrm{ml}$. Maximal stimulated CCK expression was $2.0+0.5 \mathrm{ng} / \mathrm{ml}$ for LPS, $1.8+0.6 \mathrm{ng} / \mathrm{ml}$ for sBLP, and $2.1+0.8$ for BBS; $n=4$ experiments for each condition. $* P<0.05$. 


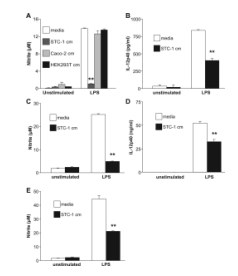

Fig. 12.

STC-1 conditioned media (cm) inhibits LPS-stimulated IL-12 p40 and nitric oxide (NO) production in macrophages. $A-E$ : 4-day conditioned media from STC-1 cells were added to RAW264.7 cells $(A)$, murine peritoneal macrophages ( $B$ and $C$ ), or murine bone marrow (BM)-derived macrophages ( $D$ and $E$ ). $A$ : 4-day conditioned media from the IEC line Caco-2 and epithelial cell line HEK-293T were used as controls. Macrophages were subsequently stimulated with $1 \mu \mathrm{g} / \mathrm{ml}$ LPS for $24 \mathrm{~h}(A, B$, and $D)$ or $48 \mathrm{~h}(C$ and $E)$. Experiments were performed in trip-licate, and results represent means $\pm \mathrm{SD}$. $* * P<0.01$ compared with media control for each group. 

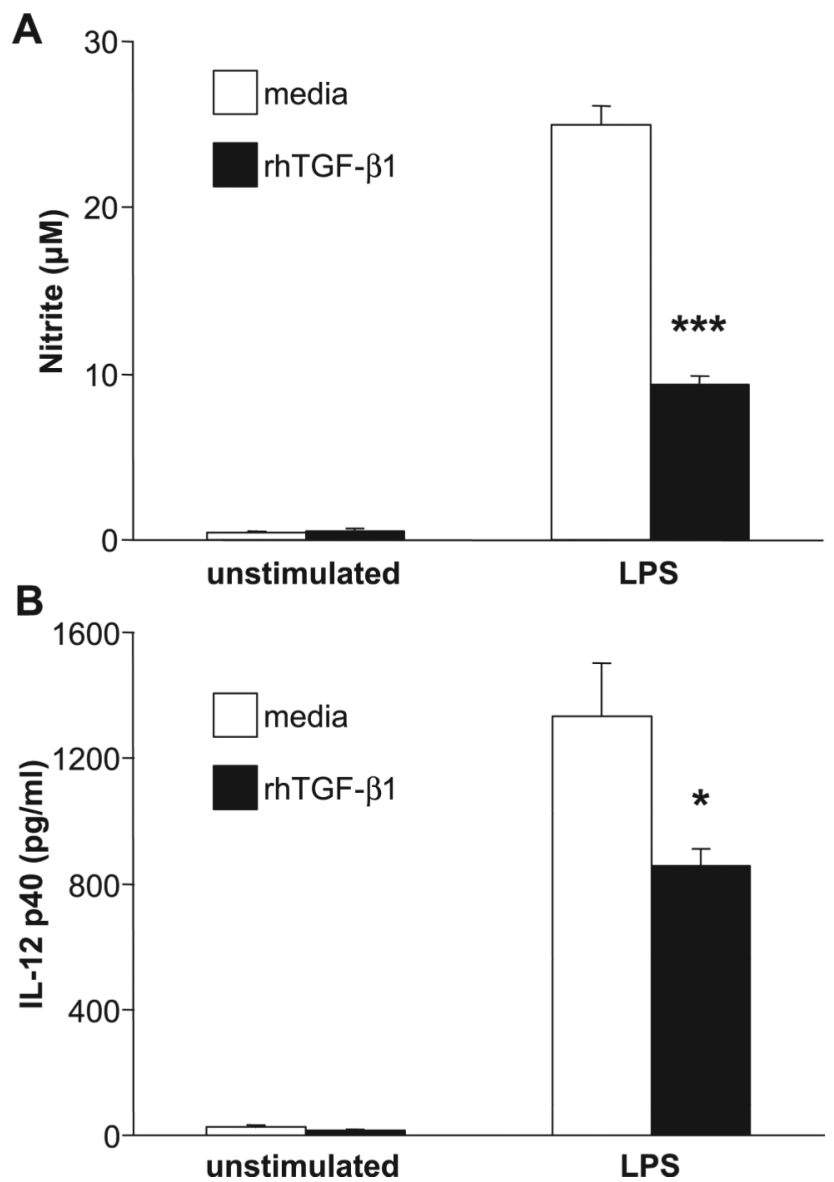

Fig. 13.

TGF- $\beta$ inhibits LPS-stimulated IL-12 p40 and NO production in macrophages. BM-derived $(A)$ or peritoneal $(B)$ macrophages were incubated with or without $5 \mathrm{ng} / \mathrm{ml}$ recombinant human (rh)TGF- $\beta 1$ prior to being stimulated with $1 \mu \mathrm{g} / \mathrm{ml}$ LPS. Supernatants were assayed for NO $(A)$ and IL-12 p40 $(B)$. Experiments were performed in triplicate, and results represent means $\pm \mathrm{SD} . * P<0.05$ and $* * * P<0.001$ compared with media control for each group. 
